\title{
Cosmeceuticals: current trends and market preparations
}

\author{
Sangeeta Kumari ${ }^{1}$ and SM Paul Khurana ${ }^{2}$ \\ Amity Institute of Biotechnology, Amity University Haryana,Gurgaon 122413
}

\begin{abstract}
In the cosmetic arena, many materials are used commercially and claim to provide skin effects (eg, antiaging effects) when used topically. Cosmeceuticals encompass a wide range of compounds of various biochemical functions. Clinically, several natural products have already been accepted to treat hyperpigmentation, wrinkles, ageing, toning and texture of the skin. In recent years various natural product have been introduced in various cosmetics for safe dermal applications with minimum side effects. The aim of this short contribution is to educate aesthetically oriented people about the basic science behind the natural products that are in use as herbals and their clinical implications. Their use needs judicious discretion on the part of user as per their skin type.
\end{abstract}

Keywords: Antiaging, antioxidants, antibacterial, skin toning, Cosmeceuticals

\section{Introduction}

"Cosmeceuticals"- a fusion of the terms "cosmetic" and "pharmaceutical" - represent one of the most promising, yet challenging treatment options available to physicians. The world known dermatologist Dr. Albert Kligman, defined the term cosmeceutical as a cosmetic product that exerts a pharmaceutical therapeutic benefit but not necessarily a biologic therapeutic benefit (1). Cosmeceuticals will contain active ingredients that are known to be beneficial to humans in some way," says Marie Jhin, MD, a dermatologist in San Francisco. "For example, vitamin $\mathrm{C}$ is a known antioxidant and when this is added to a lotion or cream the product is considered a cosmeceutical. The product label indicating botanical and marine extracts like vitamins, or peptides, it probably could be considered a cosmeceutical. In the U.S., because cosmeceuticals fall short of the legal definition of a drug but can exert therapeutic effects above and beyond those of simple cosmetics, they reside in a gray area of the 1938 Federal Food, Drug, and Cosmetic Act governing the established categories of drugs and cosmetics. Accordingly, cosmeceuticals are not regulated by the FDA. The cosmeceutical industry is based on the development and marketing of products that lie between cosmetics and pharmaceuticals. Today, there are over 400 suppliers and manufacturers of cosmeceutical products, and the industry is estimated to grow by $7.4 \%$ by 2012 . Specifically new generation as well as people of other age groups is keenly worried about their beauty. Numbers of manufacturing companies are competing to provide convincing products to cater the needs of the people of diverse age group. Cosmeceuticals like vitamins, hydroxy acid and many more have proved their efficacy in treating skin disease thus enhancing the skin texture. Yet, cosmeceuticals represent the fastest growth segment in the skin-care market, and a number of topical cosmeceutical treatments for conditions such as photoaging, hyperpigmentation and wrinkles, have come into widespread use $(2,3)$. Currently available cosmeceutical agents exert their effects through a variety of mechanisms, acting on keratinocytes, fibroblasts, as well as melanocyte.

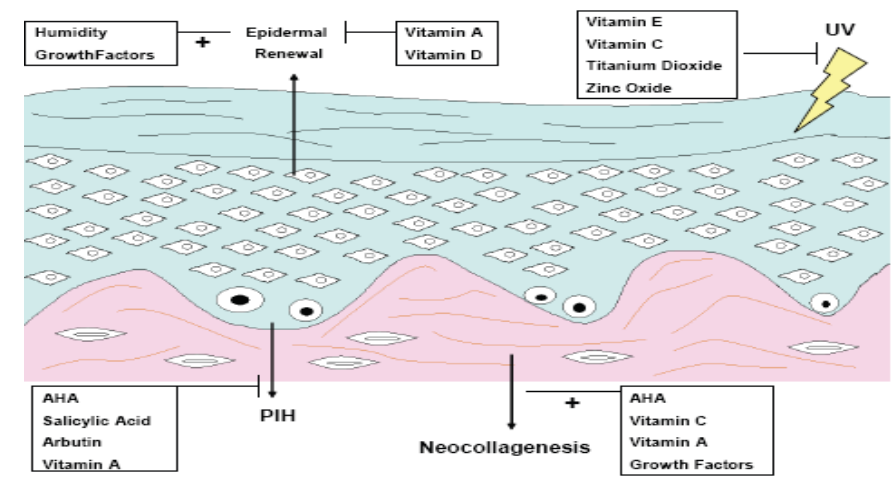

Fig.1:-Mechanisms of current cosmeceuticals agents.Alpha-hydroxyacid(AHA),post-inflammatory hyperpigmentation(PIH), ultraviolet light(UV)

Source:Thomas et al( 2008.) Clinical Medicine: Dermatology: 1

*Corresponding author: sanshnic@rediffmail.com 
There are several rapidly growing areas within the natural cosmeceutical category and hundreds of ingredients to watch as listed below:

1. Sun care-This is an area that, like aromatherapy, also encompasses most personal care areas. Companies are adding botanical ingredients, like green tea to skin care products and many others as skin damage becomes more prevalent these days. Aloe vera applied topically is accepted therapy for radiation and stasis dermatitis. It also increases collagen biosynthesis and degradation in granulation tissue. The antineoplasia effect is improved with melatonin and ascorbic acid [4]. Topical green tea extract applied to human skin provided photoprotection beginning at 24 hours and lasting for 48 to 72 hours. It reduced the number of sunburn cells by $66 \%$ when applied 30 minutes prior to UVB. This extract prevents damage caused by UV-A photo-damage with pre and post-treatment by reducing erythema, hyperplasia, and hyperkeratosis [5]. Green tea is also used to soothe sunburn, reduce baggy eyelids, and produce hemostasis. Black tea extracts applied before and after ultraviolet light challenge decreased signs of cutaneous photodamage, carcinogenesis, and inflammation in human skin. Salicyclic acid also has been shown to protect against ultraviolet (UV) B radiation and photoaging, as well as improve the appearance of photo-induced skin dyspigmentation.[6-8].

2. Antioxidants-These are related to sun care in that antioxidant protection is necessary for protecting from the sun's harmful rays, but natural antioxidants like vitamin $\mathrm{C}$ and sea buckthorn are finding their way into all kinds of skincare products as stress and pollution become more difficult to avoid in our daily lives. Curcumin may color cosmeceuticals claiming to be free of artificial ingredients. Tetrahydrocurcumin, a hydrogenated form of curcumin, is only off-white in color. It is also added to cosmeceuticals to protect the formulation and impact the skin. This antioxidant appears to be superior to tocopherol.

AHA(Alpha Hydroxy Acid) and BHA(Beta Hydroxy Acid) derivatives of salicyclic acid enhances the effect of bleaching agents such as hydroquinone In a study of 268 patients, weekly facial peels of SA $30 \%$ used for 8 weeks improved the appearance of melasma, post-acne scars, post-inflammatory hyperpigmentation $(\mathrm{PIH})$, fine lines and wrinkles.[9]

3. Anti-aging -Anti-aging is among the most dynamic of all cosmetic sand toiletries categories when it comes to pace and breadth of innovation. Consumer demands for new and better ways to reverse, delay, and prevent signs of skin aging is high and increasing. There are literally countless possible combinations and many ingredients have multiple functional properties.Centella asiatica (Gotu-Kola) is the foremost herb with antiaging effects; one of its many properties is to enhance collagen synthesis. Gotu Kola, Silk Cotton Tree and Rose Petal are the most widely used. Phyllanthus emblica (amalika), a potent antioxidant, rich in Vitamin C, tannins and gallic acid, is foremost amongst the anti-aging drugs or best amongst the rejuvenating herbs. Many skin care products containing amalika. Grapefruit extract is also natural source of Vitamins A, C and E that nourish the skin and enhance the glow of skin. Feeding the skin properly is very important to prevent it aging. A topical formulation consisting of grape seed, jojoba, lavender, rosemary, and thyme has been used in antiaging creams for several years [10].

Date Palm (Phoenix dactylifera)is used in many antiaging products. Their active compounds include 50\% sugars, such as saccharose; $10 \%$ fatty oils; oligomeric proanthocyanidins (OPC); piperidine derivatives, including pipecolic acid; and phytohormones when applied to the eyelid area twice daily for 5 weeks significantly reducted in wrinkle surface $(27.6 \%)$ and wrinkle depth was achieved [11].

4. Anti-bacterial/Anti-inflammatory-Natural cosmeceuticals now address skincare problems like acne and other types of inflammation, including wound healing and rashes along with many others. Ingredients such as avocado, tea tree oil, and even rosemary have properties dealing with these issues. Tree bark extracts, including that of Quercus rubras, have been used traditionally by the native elders of Vancouver Island to treat illnesses ranging from digestive tract ailments to dermatologic complaints [12]. Oak bark contains tannin and has a significant astringent property that is thought to coagulate surface proteins of cells, which causes a reduction in permeability and secretions [13]. The reduced skin irritation observed with salicyclic acid relative to conventional topical acne treatments has been attributed to its anti-infl ammatory effects.[14] It is possible that the benzoic and salicylic acids that are found in the oak bark extract may have contributed to its antimicrobial effects, because both have been shown to have antimicrobial activity $[15,16]$. Similarly, Alpha-Hydroxyl acids, exert anti-infl ammatory effects as well as increase epidermal cell turnover resulting in exfoliation of skin.[17] Since clinical trials are not mandated for cosmeceuticals, the efficacy of these compounds is often questioned by physicians and the public alike. Innovative product ideation, new research and science, and the ever-changing consumer and retail space all contribute to the beauty industry. Modern medicine is rooted in ethnobotanical traditions using indigenous flora to improve specific aspects of the body condition. Herbal medicine is now used by over half of the world population. Over 60 botanicals are marketed in cosmeceutical formulations, dermatologists need to obtain working knowledge of the major botanicals. The most important botanicals pertaining to dermatologic uses, such as cosmeceuticals, include soyabean, pomegranate, date, grape seed, 
German chamomile, curcumin, and aloe. These herbals are among the most commonly used by the public and expected to continue to be the most commonly used in cosmeceuticals for topical formulations.

Many more herbs and their natural compounds are documented to treat dermatologic conditions. The mechanisms of action, source, and market preparations are discussed below.

Table 1: Natural compounds used as cosmeceuticals and available market preparations

\begin{tabular}{|c|c|c|c|}
\hline Ingredient & Action & Source & Market preparations \\
\hline Aloe-vera & Softens skin & Aloe-vera & $\begin{array}{l}\text { Naturesgel, Aloe-vera } \\
\text { gel Patanjali }\end{array}$ \\
\hline Alpha hydroxyl acid & $\begin{array}{l}\text { Exfoliates and improves } \\
\text { circulation }\end{array}$ & $\begin{array}{l}\text { Fruit acids ( Glycolic } \\
\text { acid, Lacticacid, maleic } \\
\text { acid, Citric acid) }\end{array}$ & $\begin{array}{l}\text { Garnier anti wrinkles, } \\
\text { Olay anti wrinkle } \\
\text { cream, Himalaya anti } \\
\text { wrinkle cream, Aroma } \\
\text { Magic }\end{array}$ \\
\hline Arnica & Astringent \& soothing & Arnica montane & Arnica herbal cream \\
\hline Beta Hydroxyl acid & Antibacterial & $\begin{array}{l}\text { Salicyclic acid } \quad \text { (Salix } \\
\text { alba) }\end{array}$ & $\begin{array}{lr}\text { Oxy } & \text { med } \\
\text { shampoo,Skin } & \text { Medica } \\
\text { face cream } & \end{array}$ \\
\hline Boswelia & $\begin{array}{l}\text { Anti-inflammatory \& Anti } \\
\text { aging }\end{array}$ & Boswellia serrata & $\begin{array}{l}\text { Aromaboswelia } \\
\text { antiwrinkle cream }\end{array}$ \\
\hline Beta carotene & $\begin{array}{l}\text { Minimizes lipid } \\
\text { peroxidation and cellular } \\
\text { antioxidant }\end{array}$ & Carrot \& Tomato & Evion cream \\
\hline Calendula & $\begin{array}{lr}\begin{array}{l}\text { Soothes, } \\
\text { skin,promotes }\end{array} & \begin{array}{r}\text { softens } \\
\text { cell } \\
\text { formation }\end{array} \\
\end{array}$ & Calendula officinalis & Calendula cream \\
\hline Centella & $\begin{array}{l}\text { Skin conditioning agent, } \\
\text { increase collagen,improves skin } \\
\text { texture, reduces strech mark }\end{array}$ & Centella asciatica & $\begin{array}{l}\text { Keratin complex } \\
\text { cream, Esttle Lauder, } \\
\text { Ponds }\end{array}$ \\
\hline Corriander seed oil & $\begin{array}{lll}\text { Anti inflammatory } & \& & \text { skin } \\
\text { lightening properties } & & \\
\end{array}$ & Coriander sativa & $\begin{array}{l}\text { Richmond } \\
\text { nature cream }\end{array}$ \\
\hline Cucumber & $\begin{array}{l}\text { Cellular antioxidant, refreshes } \\
\text { and tighten pores }\end{array}$ & Cucumis sativus & Everyouth cream \\
\hline Green tree extract & Anti oxidant & Green tea & $\begin{array}{l}\text { Alba botanica } \\
\text { moisturizer }\end{array}$ \\
\hline Kinetin & $\begin{array}{l}\text { Free radical scavenger and } \\
\text { antioxidant }\end{array}$ & Yeast & Kinerase protherapy \\
\hline Licorice extract & Skin whightening & Glycyrriza glabra & Liqourice balm \\
\hline Neem oil & Anti microbial & Azadiracta indica & $\begin{array}{l}\text { Himalaya neem face } \\
\text { wash }\end{array}$ \\
\hline Rosemary extract & Antioxidant,Antimicrobial & Rosemarinus officinalis & Loreal body cream \\
\hline Turmeric oil & Antimicrobial, Anti oxidant & Curcuma longa & Vicco turmeric cream \\
\hline Vitamin -A & Antioxidants & $\begin{array}{l}\text { Vit A,C,E( lemon,citrus } \\
\text { fruit, Essential oils }\end{array}$ & Everyouth peel \\
\hline Witch hazel & Tones skin & Hamamelis viginiana & $\begin{array}{l}\text { Thayers skin toner, } \\
\text { Witch hazel cream }\end{array}$ \\
\hline
\end{tabular}

\section{Conclusion}

The present text aims to highlight the blooming skin cosmeceuticals industry that offers limitless possibilities for identifying new functional materials as well explore the existing classes of compounds. . The usage of cosmeceuticals has radically risen in recent years which has broadened their range of products to enhance comliness of skin .Clearly, there is quite a lot going on in the world of natural cosmeceuticals. Natural personal care is growing more rapidly than any other area in use of natural products, besides organic foods, and therefore offers much more opportunity for both the small natural products manufacturers and the mainstream personal care company that strives to produce truly natural products. The rise of this gray area category can be largely attributed to the national trend toward self-treatment, environmental awareness and overall health and wellness. Consumer attitudes and behavior must be tracked and measured so that companies can produce suitable items and market the right products for the appropriate target.

\section{References}

[1.] Brody, H.J. Relevance of cosmeceuticals to the dermatologic surgeon. Dermatol. Surg., 31(2), 2005:796-8.

[2.] Sadick, N.S. Cosmeceuticals. Their role in dermatology practice.J. Drugs Dermatol.,2(5), $2003: 529-37$.

[3.] Vermeer, B.J. and Gilchrest, B.A. Cosmeceuticals. A proposal for rational definition, evaluation, and regulation. Arch. Dermatol., 132(3),1996:337-40.

[4.] Baumann LS. (2003 )Cosmeceutical critique: aloe vera. Skin \& Allergy ,News.,34:32. 
[5.] Zhao F, Zhang YJ, Jinx H. Green tea protects against psoralen plus ultraviolet A induced photochemical damage to skin. J Invest Dermatol.113, 1999:1070-5.

[6.] Shaath, N. Evolution of modern chemical sunscreens. In: Lowe N.J., (editor) Physicians guide to sunscreens. New York: Marcel Dekker, 1991:161-5.

[7.] Kligman, A.M. A comparative evaluation of a novel lowstrength salicylic acid cream and glycolic acid products on human skin. Cosmet. Dermatol., 10( 4),1997:11-15.

[8.] Freedberg, I.M. and Baden, H.P. The metabolic response to exfoliation. J. Invest. Dermatol., 38,1962:277-84.

[9.] Engasser, P.G. and Maibach, H.I) Cosmetic and dermatology: bleaching creams. J. Am. Acad. Dermatol., 5(2),1981:143-7.

[10.] Hey IC, Jamieson M, Ormerod AD.Randomized trial of aromatotherapy.Arch Dermatol.,134, $1998: 1349-52$.

[11.] Bauza E, Dal Farra C, Berghi A. Date palm kernel extract exhibits antiagingproperties and significantly reduces skin wrinkles. Int J Tissue React., 24,2002:131-6.

[12.] Turner NJ, Hebda RJ. (1990) Contemporary use of bark for medicine by two Salishan native elders of southeast Vancouver Island, Canada. J Ethnopharmacol., 29,1990:59-72.

[13.] Brown DJ, Dattner AM. Phytotherapeutic approaches to common dermatologic conditions. Arch Dermatol.,134: 1998,1401-4.

[14.] Davis, D.A., Kraus, A.L., Thompson, G.A., Olerich, M. and Odio, M.R. Percutaneous absorption of salicylic acid after repeated (14-day) in vivo administration to normal, acnegenic or aged human skin. J. Pharm. Sci., 86(8), 1997:896-9.

[15.] Ivanova A, Delcheva I, Tsvetkova I, Kujumgiev A, Kostova I. GC-mS analysis and anti-microbial activity of acidic fractions obtained from Paeonia peregrina and Paeonia tenuifolia roots. Z Naturforsch [C]. 57, 2002:624-8.

[16.] Polonio RE Mermel LA, Paquette GE, Sperry JF.Eradication of biofilm-forming Staphylococcus epidermidis (RP62A) by a combination of sodium salicylate and vancomycin. Antimicrob Agents. Chemother.,45,2001: 3262-6.

[17.] Brody, H.J. Relevance of cosmeceuticals to the dermatologic surgeon. Dermatol. Surg., 31(7 Pt 2),2005:796-8. 